Pesq. Vet. Bras. 38(1):53-58, janeiro 2018 DOI: $10.1590 / \mathrm{S} 0100-736 \mathrm{X} 2018000100009$

\title{
Bacteriological, cytological and histopathological evaluation of the reproductive tract of slaughtered cows ${ }^{1}$
}

\author{
Julia B.S. Casarin ${ }^{2 *}$, Ana P. Martini², Janislene M. Trentin ${ }^{3}$, Mariani F. Fiorenza ${ }^{3}$, \\ Gilson A. Pessoa ${ }^{2}$, Severo S. Barros ${ }^{2}$ and Mara I.B. Rubin ${ }^{2}$
}

\begin{abstract}
Casarin J.B.S., Martini A.P., Trentin J.M., Fiorenza M.F., Pessoa G.A., Barros S.S. \& Rubin M.I.B. 2018. Bacteriological, cytological and histopathological evaluation of the reproductive tract of slaughtered cows. Pesquisa Veterinária Brasileira 38(1):53-58. Departamento de Medicina de Grande Animais, Universidade Federal de Santa Maria, Avenida Roraima 1000, Santa Maria, RS 97105-900, Brazil. E-mail: juliaspreckelsen@gmail.com

Reproductive diseases, mainly endometritis, are important hurdles in cattle raising, In the current study we evaluated gross, bacteriological, cytological, and histological findings from selected sites of the genital from 23 slaughtered cows and tested whether there is an association between these findings and the probability of reaching a reliable diagnosis. The results from the examinations of macroscopic aspects of uterine secretions, the cytological, bacteriological, and histopathological findings were then correlated. There was no significant correlation $(\mathrm{P}>0.05)$ of the statistical data from different parts of the genital tract. Trueperella pyogenes and Escherichia coli were isolated from the vagina in 3/23 cases. In only 2/23 samples Enterococcus faecalis and a gram-negative, oxidase-positive bacteria were isolated from the cervix uteri. Only Staphylococcus epidermidis, in 1/23 case, was isolated from the uterus. Histopathological findings in uterus from samples of Groups II (moderate lesions) and III (severe lesions) did not translated in grossly visible changes. Samples from reproductive tracts with secretion in the vagina and cervix uteri had no detectable changes in the other parameters analyzed from this portion. Uterus with positive bacterial culture had evidence of ascendant inflammation judging by the high granulocyte count in the three analyzed portions. This study reinforces that vaginitis and cervicitis in the cow diagnosed only by clinical examination does not reflect the real status of the uterine health. For this reason, treatment of uterine disorders should be conducted based on reliable tests to determine the appropriate therapy for each situation.
\end{abstract}

INDEX TERMS: Cattle diseases, reproductive diseases, reproductive tract, endometritis.

RESUMO.- [Avaliação bacteriológica, citológica e histopatológica do trato reprodutivo de vacas abatidas.] Doenças reprodutivas causam altas perdas econômicas nos rebanhos bovinos, sendo a endometrite uma das alterações mais relevantes. Os objetivos desta pesquisa foram avaliar a associação dos achados fisiopatológicos em exames macroscópicos, bacteriológicos, citológicos e histopatológicos

\footnotetext{
${ }^{1}$ Received on December 22, 2016.

Accepted for publication on April 9, 2017.

${ }^{2}$ Departamento de Clinica Grandes Animais, Universidade Federal de Santa Maria (UFSM), Av. Roraima 1000, Camobi, Santa Maria, RS 97105900, Brazil. *Corresponding author: juliaspreckelsen@gmail.com

${ }^{3}$ Departamento de Medicina Animal, Universidade Federal do Rio Grande do Sul (UFRGS), Av. Bento Gonçalves 9090, Bairro Agronomia, Porto Alegre, RS 91540-000, Brazil.
}

nas porções do trato genital de 23 vacas abatidas, bem como avaliar a necessidade de associação destes exames para efetuar diagnóstico fidedigno. A avaliação macroscópica da secreção, os exames histopatológico, citológico e as bactérias identificadas foram correlacionados. Não houve associação $(\mathrm{P}>0,05)$ dos resultados nas diferentes porções do trato genital. Na vagina foram isoladas as bactérias Trueperella pyogenes e Escherichia coli. Na cérvix, em apenas 2/23 (8,6\%) amostras isolou-se Enterococcus faecalis e gram negativo oxidase positiva. No útero houve isolamento apenas da bactéria Staphylococcus epidermidis. As amostras histopatológicas classificadas em grupo II e III não apresentaram alterações detectadas no exame macroscópico. As amostras com secreção não fisiológica na vagina e cérvix não apresentaram alterações nos outros exames na porção uterina. A amostra com cultura bacteriológica positiva no útero de- 
monstrou uma infecção ascendente através da alta contagem de granulócitos nas três porções analisadas. 0 presente estudo reforça o conceito de que a vaginite e cervicite diagnosticadas pelo exame clinico na vaca não retratam o real status da saúde uterina e por esta razão, o tratamento do útero deve ser conduzido com critério, alicerçado nos exames complementares para definir a terapia adequada para cada situação.

INDEX TERMS: Endométrio, granulócitos, trato reprodutivo, bactérias, bovinos.

\section{INTRODUCTION}

Profitability in cattle raising industry is closely related with a sound reproductive capacity. Reproductive problems are usually multifactorial regarding their causes. Endometritis and metritis are probably the most important pathological conditions of the reproductive tract of cows and responsible for increased intervals between calving, repeated heats, decreased rate of conception, and infertility.

Physiologically, before deliverance the uterine lumen is sterile. However if bacterial invasion does occur it could induce fetal reabsorption or abortion (Semambo et al. 1991, Sheldon 2009). A large spectrum of bacteria was isolated from the uterus of $>90 \%$ of cows soon after parturition and this prevalence of infection decreases with time (Elliott et al. 1968).

Different diagnostic methods, including vaginal examination, Metricheck device, ultrasonography, cytology and uterine biopsy have been used to evaluate uterine health status and to orient therapy in cases where pathological conditions are found.

Uterine contaminant bacteria are nonspecific and belong to a great number of bacterial species (Griffin et al. 1974, Sheldon et al. 2002). A number of bacteria, namely Streptococcus spp., Staphylococcus spp. and Bacillus spp., have been isolated from the uterus of cows without signs or puerperal metritis (Huszenicza et al. 1999) while Trueperella pyogenes, Escherichia coli, Fusobacterium necrophorum, Prevotella melaninogenicus, Bacteroides spp. and Clostridium, spp. were detected in the uterus from cows with endometritis (Bondurant 1999, Huszenicza et al. 1999, Mateus et al. 2002). The uterine biopsy is ideally used for evaluation of endometrial morphology since the small sample for histological examination is representative of the whole endometrial mucosa. (Bonnett et al. 1991). When the uterus is infected, inflammatory cells infiltrate the endometrium and other acute and chronic inflammation occur (Cordeiro et al. 1989a); those include necrosis, hyperemia, increased numbers of neutrophils, lymphocytes, and macrophages, cystic dilatation of endometrial glands or atrophy associated with compromised reproductive performance (Cordeiro et al. 1989a).

Cytology is an efficient method to evaluate uterine infections in cows (Cordeiro et al. 1989b). Additionally, as pointed out elsewhere neutrophils are the main defense line against infectious agents and there is an accumulation of these cells in the endometrium (Watson, 1990, Butt et al. 1991). Neutrophils will hereafter be referred to as granulocytes in order to accommodate eosinophils and basophils under this denomination.
Examining the general clinical and specific aspects of the reproductive tract of the cow it is hoped that the reproductive changes encountered at gross examination correlate with laboratorial exams. It is hypothesized here that the bacteria found in the vagina and cervix uteri of cows with endometritis do not differ from those found in the endometrium. Based on this hypothesis the necessity of invasive uterine diagnostic methods are questioned as when inflammatory changes can be detected by clinical examination in the vagina and/or cervix uteri.

The objective of this study was to evaluate whether there is an association between macroscopic, bacteriological, cytological and histopathological findings in the reproductive tract of slaughtered cows and if this putative association would allow for a reliable diagnosis.

\section{MATERIALS AND METHODS}

Animal care and approval. Study design, collection of specimens of was approved by the Ethical Committee of the UFSM and registered under the number 3737040216.

Animals and study design. The study was carried out at the Laboratório de Embriologia Animal (Embryolab) of the Universidade Federal de Santa Maria (UFSM), Southern Brazil, using the grossly healthy reproductive tract (hereafter referred as specimens) of 23 clinically normal slaughtered cows. The specimens were collected at local abattoirs from August to December 2015.

Sampling. The specimens of slaughtered cows were collected at random in plastic trays previously disinfect with $70 \%$ ethanol and cover with sterile surgical field. Each portion of the specimen was cleaned with $70 \%$ ethanol immediately before sampling which was performed with gloved hands directly from each portion of the specimen to be analyzed through an incision using a scalpel with a new sterile blade for each portion.

All the portions of the collected specimens were grossly examined for detection of secretion and integrity of the mucosa of vagina, cervix uteri, and uterine horns. Data were written down in a spreadsheet for future correlation. Presence or absence of secretion was classified as (1) absent; (2) clear and translucent mucous; (3) yellow mucous; (4) bloody mucous; (5) mucopurulent; and (6) bloody mucous associated with and edematous specimen wall. Gross aspect classification as 3-5 was considered potentially indicative of inflammation.

Samples for bacteriology and cytology were taken from the cervix uteri, vagina, and from the left uterine horn. Bacteriological and cytological samples were consistently taken in the following sequence: uterine horn, cervix uteri and vagina. From the left horn the bacteriological sample was obtained through the insertion of sterile swab (Absorve ${ }^{\circledR}$, Citotest Labware Manufacturing CO, China). The collected sample was placed in Stuart medium, identified and kept in a thermos with recycled ice packets. From the same incision, sampling done for cytology was made using a gynecological brush $\left(\right.$ Vagispec $^{\circledR}$, Adlin Plásticos LTDA, Jaraguá do Sul, Brazil). Immediately after sampling, a smear was made with the brush on glass histological slides, which were dried at room temperature. The same procedures were applied to cervix uteri and vagina.

Using a sterile scalpel and scissors $3 \times 2 \mathrm{~cm}$ endometrial biopsies were taken from the right uterine horn and fixed in Bouin's solution.

Processing and evaluation of samples. Samples for bacteriology were sent to a reference laboratory accredited IS09001 for bacterial isolation and identification. 
Samples (smears) for cytological examination were stained with panoptic stain (Laborclin ${ }^{\circledR}$, São José dos Pinhais, Brazil). Cells were identified as epithelial, lymphocytes, monocytes, and granulocytes. One hundred cells were counted in each slide. Endometritis were considered when and excess of $10 \%$ granulocytes counted.

The excess Bouin's solution was cleansed from fixed endometrial fragments by successive alcohol baths and then routinely processed for histopathology Histological findings were classified as shown in Table 1.

Statistical analysis. The obtained data were organized in order to evaluate the association among the results of the various examinations carried out in each portion of the specimen and among different portions of the specimen with each exam. To evaluate the results of uterine histopathology the Comparison of

Table 1. Classification of histological findings in the 23 reproductive tracts collect from slaughtered cows

\begin{tabular}{|c|c|}
\hline Group & Histological findings \\
\hline I & $\begin{array}{l}\text { Endometrium either without pathological changes or with mild } \\
\text { changes, such as mild inflammatory mononuclear focal infiltrate, } \\
\text { mild focal periglandular fibrosis and a few dilated glandular lu- } \\
\text { mina. }\end{array}$ \\
\hline II & $\begin{array}{l}\text { Endometrium with more severe changes than those of Group I, } \\
\text { such as diffuse granulocyte infiltrate, moderate mononuclear in- } \\
\text { filtrate with or without lymphoid nodules. Moderate focal fibrosis } \\
\text { with or without associated mild to moderate dilatation of some } \\
\text { glandular lumina. }\end{array}$ \\
\hline III & $\begin{array}{l}\text { Endometrium with severe pathological changes which would } \\
\text { significantly compromise fertility. These changes include diffuse } \\
\text { mononuclear infiltrate associated or not with lymphoid follicles, } \\
\text { multifocal or diffuse fibrosis, regardless of the degree of severity, } \\
\text { and glandular nests with dilated glandular lumina; endometrial } \\
\text { hypoplasia; pyometra; endometrial atrophy. }\end{array}$ \\
\hline
\end{tabular}

Paired Proportions Test was applied, grouping the data of macroscopic, bacteriological and cytological findings. For the cervix uteri and vagina, and the absence or presence of secretion with pathological aspect. Paired Proportions Comparison Test was applied to granulocytes $<10$ and granulocytes $>10$, and bacteriology positive or negative. Results as $\mathrm{P}<0.05$ were considered statistically different.

\section{RESULTS}

Data on the evaluation of the different portions of the reproductive tract of the 23 slaughtered cows and the results of Paired Proportions Comparison Test applied to the different parts of the reproductive tract are summarize respectively in Table 2 and 3.

\section{Vagina}

Two of the 23 samples had secretion of yellow mucous, $7 / 23$ had translucent mucous secretion and in 14/23 secretion was not detected. Results of cell counting in cytological slides were as folows: in 8/23 there was a proportion $\geq 10 \%$ of granulocytes. Only $3 / 23$ of the samples yielded bacterial growth, one of T. pyogenes and two of E. coli. There was no significant relationship of statistical data $(\mathrm{P}>0.05)$ when the correlation of bacteriological, histological exams was applied vaginal samples.

\section{Cervix uteri}

Two out of 23 samples displayed yellow mucous; in $2 / 23$ samples had translucent mucous and in 19/23 secretion was not observed. In the evaluation of the cytological slides $3 / 23$ samples had a proportion $\geq 10 \%$ of granu-

Table 2. Data on the evaluation of the different portions of the reproductive tract of 23 slaughtered cows

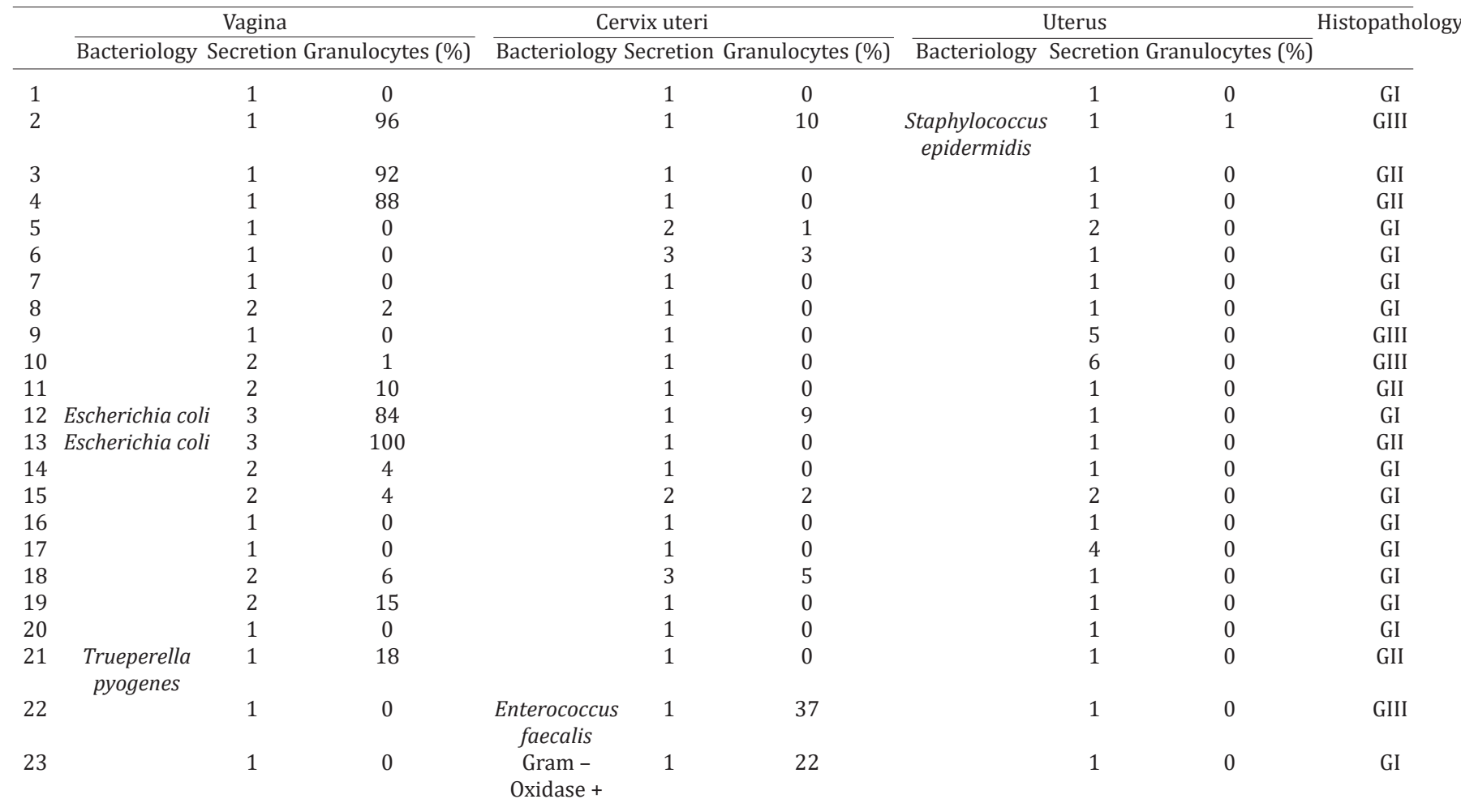

Secretion: (1) absent; (2) clear and translucent mucous; (3) yellow mucous; (4) bloody mucous; (5) mucopurulent; and (6) bloody mucous associated with and edematous specimen wall. 
Table 3. Relationship of the histopathology (Groups I and III) with gross characteristic of uterine secretion, granulocytes per 100 cells and bacteriological culture, and relationship of the proportion granulocytes per 100 cells, granulocytes per 100 cells with the gross aspect of the secretion sampled from the lumen of the cervix uteri, vagina and uterus from 23 slaughtered cows

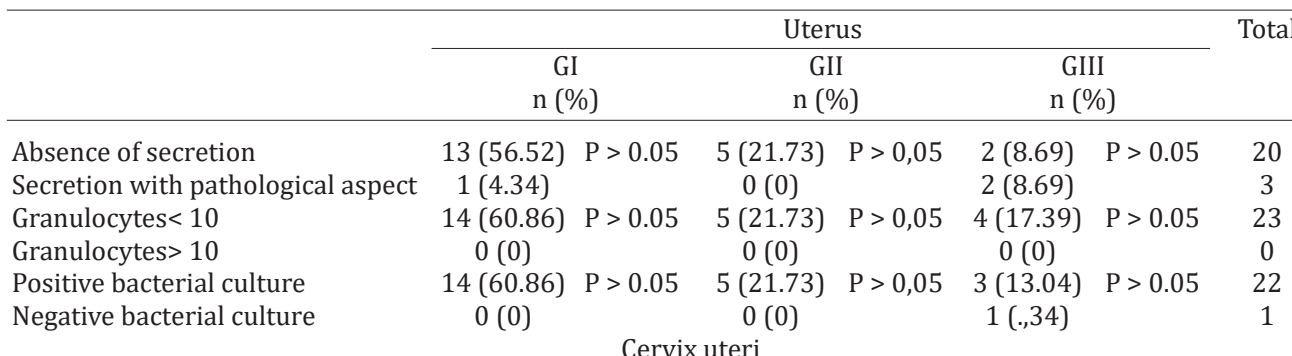

Absence of secretion Secretion with patho-

ogical characteristics

Granulocytes $<10$

Granulocytes $>10$

Positive bacterial culture

Negative bacterial culture

$$
\begin{aligned}
& 18 \text { (78.26) } \mathrm{P}>0.05 \quad 2(8.69) \quad \mathrm{P}>0.05 \\
& 3(13.04) \\
& 19 \text { (82.60) } \mathrm{P}>0.05 \quad 2(8.69) \quad \mathrm{P}>0.05 \\
& 2 \text { (8.69) } \\
& 0(0)
\end{aligned}
$$

$\begin{array}{cc}- & 20 \\ - & 3 \\ - & 21 \\ - & 2\end{array}$

Absence of secretion Secretion with pathological characteristics

$\begin{array}{lc}\text { Granulocytes }<10 & 15(65.21) \mathrm{P}>0,05 \\ \text { Granulocytes }>10 & 6(26.08) \\ \text { Positive bacterial culture } & 20(86.95) \mathrm{P}>0,05 \\ \text { Negative bacterial culture } & 1(4.34)\end{array}$

n $(\%)$

$15(65.21) \mathrm{P}>0,05$

20 (86.95) $\mathrm{P}>0,05$

$1(4.34)$

$$
\begin{array}{cc}
\multicolumn{2}{c}{\mathrm{n}(\%)} \\
0(0) & \mathrm{P}>0.05 \\
2(8,69) & \\
0(0) & \mathrm{P}>0.05 \\
2(8.69) &
\end{array}
$$

GI (Group I) Endometrium either without pathological changes or with mild changes, such as mild inflammatory mononuclear focal infiltrate, mild focal periglandular fibrosis and a few dilated glandular lumina.

GII (Group II) Endometrium with more severe chances than those of GI, such as diffuse neutrophilic infiltrate , I moderate, mononuclear infiltrate with or without lymphoid nodules. Moderate focal fibrosis with or without associated mild to moderate dilatation of some glandular lumina.

GIII (Group III) Endometrium with severe pathological changes which would significantly with fertility. These changes include diffuse mononuclear in filtrate associated or not with lymphoid follicles, multifocal or diffuse fibrosis regardless of the degree of severity and glandular nests with dilated of glandular lumina; endometrial hypoplasia; pyometra; endometrial atrophy.

locytes. Bacterial culture yielded Enterococcus faecalis in $1 / 23$ and a gram-negative, oxidase-positive bacterium in another one $(1 / 23)$.

\section{Uterus}

In eighteen out of the 23 examined uteri no secretion was observed. In the remaining 5 samples, 2 had translucent mucous, one had bloody mucous, one had mucopurulent secretion and in one case the uterus was hemorrhagic and edematous.

Bacterial culture yielded Staphylococcus epidermidis from two samples out of the 23 examined.

Moderate histopathological changes (Group II) were found in 5/23 of the endometrial samples, and severe lessions in $4 / 23$ of the samples. The Paired Proportions Comparison Test applied to uterine samples per each group shows that the results are not necessarily correlated. This statement is based in the macroscopic evaluation of the secretion, percentage of granulocytes, bacterial data, and also the gross examination of the cervical and vaginal secretions compared with the cytological results. In 3 / 23 of the samples microscopic inflammatory exudate was found but no bacteria was isolated from these samples.

The results from gross, bacteriological, cytological and histopathological exams from the vagina, cervix uteri, and uterus are in Table 2.

\section{DISCUSSION}

The pathogenesis of uterine diseases was investigated by several research groups (Thurmond et al. 1993, LeBlanc et al. 2002, Chenault et al. 2004, Kasimanickam et al. 2005, Goshen \& Shpigel 2006, Galvão et al. 2009) and there is a well stablished consensus that endometritis strongly compromises the reproductive performance of cows (Hartmann et al. 2016). Routine diagnostic method used by veterinarian practitioners to identify uterine changes consists in a thorough gynecological exam, which includes rectal and vaginal clinical examination. Uterine diseases in reproductive purpose cows of are classified as puerperal metritis, clinical metritis, clinical endometritis and subclinical endometritis (Sheldon et al. 2006).

Clinical endometritis is characterized by purulent ( $>50 \%$ of pus) or mucopurulent ( $50 \%$ pus, $50 \%$ mucous) uterine discharge (Sheldon et al. 2006). Endometritis is generally diagnosed by examining the uterus trough transretctal palpation to evaluate size, horn symmetry, uterine fluctuation (Grunert 1979) and examining uterine discharge with the help of (1) a vaginal speculum (LeBlanc et al. 
2002), (2) of the Metricheck device (McDougall et al. 2001), and (3) by transretctal palpation with gloved hand (Williams et al. 2005).

In the current study was a lack of correlation between the presence of vaginal and/or cervical secretion and the presence of uterine disease; nor could be established a correlation between the secretion and complementary exams (bacteriological, cytological and histopathological). These findings strength the assertion that the evaluation of non-physiological vaginal secretion is not a reliable diagnostic method for bovine endometritis (McDougall 2001). Recently, the prevalence of cervicitis and its effects in the reproductive performance were studied in dairy cows 42 50 days after parturition through rectal and vaginal exam, cervical and uterine cytology with Citobrush, and endometrial biopsy (Hartmann et al. 2016). Conception rate in cows $(n=157)$ with severe cervicitis and endometritis decreased dramatically (29\%) while the conception rates in cows with only cervicitis was 34\%. The authors suggest that cervicitis occurs independently from endometritis, since in $66.3 \%$ of the exams cervicitis without endometritis was identified. Thus the association of complementary exams is fundamental for the definitive diagnosis.

Although the results of the current study were obtained from specimens collected from slaughtered cows without individual clinical histories, the data clearly demonstrate the need of performing complementary exams to obtained a more accurate information on the uterine status and the related fertility.

The histopathological uterine lesion score shows interesting data. It was found that in $9 / 23$ of the uterus the endometrial lesion score was within Groups II and III, demonstrating that these cows had some degree of fertility compromise. However, only from one cow (Cow 2 in Table 2), a microorganism, S. epidermidis, was isolated. Although additional studies are desirable to confirm some of our data, these results suggest that is probable the degree of endometrial inflammation and atrophy do not correlate with bacterial infection.

Out of the 23 reproductive tracts studies 12 had some type of change identified by the complementary exams (Table1). The most severe change was observed in Cow 2, which presented vaginitis, cervicitis and endometritis diagnosed by the presence of $>10 \%$ of granulocytes and positive bacterial cultures.

Two cows (22 and 23) presented only cervicitis diagnosed by the presence of $>10 \%$ of granulocytes positive bacterial cultures. Seven cows $(3,4,11-13,19$ and 21) presented vaginitis, diagnosed by the presence of $>10 \%$ of granulocytes in the cytological examination. These data convey that the main criteria for culling cows for slaughter should be the pathological changes in the reproductive tract.

Additionally, these results show that the bacteria presence is generally associated with granulocyte presence, but the inverse is not always true. Bacteriology detected Escherichia coli in the vaginal portion in two samples in which the presence of $>84 \%$ and $100 \%$ of granulocytes was counted on cytological exam and in which, the macroscopic examination detected secretion with pathological characteristics. However, in the cervix uteri and uterus there were no bacterial growth in the absence of abnormal secretion. Trueperella Trueperella pyogenes pyogenes was cultured from the vaginal portion of one of the reproductive tracts in which $18 \%$ of granulocytes was counted on cytological exam.

One of the main uterine problems causing important economic losses is subclinical endometritis (Galvão 2012). This disease is defined by the presence of $>10 \%$ of granulocytes in the endometrium (Sheldon et al. 2006). None of uterine samples of the current study revealed de right numbers of granulocytes to characterize subclinical endometritis as it is defined (Galvão 2012).

The current study reinforces the concept that vaginitis and cervicitis in the cow diagnosed by the clinical exam do not translate the real uterine health status and, for this reason, the treatment of uterine disease should be conduct within criteria based on complementary exams, which will define the proper therapy in each occasion.

Acknowledgments.- The authors are great full to Prof. DMV, MSc. PhD Claudio Severo Lombardo de Barros for his valuable work editing this manuscript in English. This research was sponsored by Embryolab/UFSM-RS/Brazil, and CNPq provided scholarship to the first author.

\section{REFERENCES}

Bondurant R.H. 1999. Inflammation in the bovine female reproductive tract. J. Anim. Sci. 77(2):101-110.

Bonnett B.N., Martin S.W., Gannon V.P., Miller R.B. \& Etherington W.G. 1991. Endometrial biopsy in Holstein-Friesian dairy cows. III. Bacteriological analysis and correlations with histological findings. Can. J. Vet. Res. 55(2):168-173.

Butt B.M., Senger P.L. \& Widders P.R. 1991. Neutrophil migration into bovine uterine lumen following intrauterine inoculation with killed Haemophilus somnus. J. Reprod. Fertil. 93(2):341-345.

Chenault J.R., Mcallister J.F., Chester J.R., Dame K.J., Kausche F.M. \& Robb E.J. 2004. Efficacy of ceftiofur hydrochloride sterile suspension administered parenterally for the treatment of acute postpartum metritis in dairy cows. J. Am. Vet. Med. Assoc. 224:1634-1639.

Cordeiro J.L.F., Barros S.S. \& Neves J.P. 1989a. Avaliação histopatológica do endométrio de vacas leiteiras com catarro genital. Revta Bras. Reprod. Anim. 13(1):7-14.

Cordeiro J.L.F., Neves J.P., Fan L.C.P., Albuquerque A.J.D., Badke M.R.T. \& Silva J.H.S. 1989b. Citologia cérvico-uterina para o diagnóstico de catarros genitais na vaca. Revta Bras. Reprod. Anim. 13(1):53-68.

Elliott L., McMahon K.J., Gier H.T. \& Marion G.B. 1968. Uterus of the cow after parturitionwith bacterial content. Am. J. Vet. Res. 29(1):77-81.

Galvão K.N., Greco L.F., Vilela J.M., Sá Filho M.F. \& Santos J.E.P. 2009. Effect of intrauterine infusion of ceftiofur on uterine health and fertility in dairy cows. J. Dairy Sci. 92:1532-1542.

Galvão K.N. 2012. Enfermidades uterinas durante o período pós-parto em vacas de leite. Anais XXVI Reunião Anual da Sociedade Brasileira de Tecnologia de Embriões, Foz do Iguaçu, p.184-190.

Griffin J.F.T., Hartigan P.J. \& Nunn W.R. 1974. Non-specific uterine infection and bovine fertility. I. Infection patterns and endometriosis during the first seven weeks postpartum. Theriogenology 1(3):91-106.

Grunert E. 1979. Female genital system, p.323-350. In: Rosenberger G. Dirksen G., Gründer H.D., Grunert E., Krause D. \& Stöber M. (Eds), Clinical Examination of Cattle. Paul Parey, Berlin.

Goshen T. \& Shpigel N.Y. 2006. Evaluation of intrauterine antibiotic treatment of clinical metritis and retained fetal membranes in dairy cows. Theriogenology 66:2210-2218. 
Hartmann D., Rohkohl J., Merbach S., Heilkenbrinker T., Klindworth H.P., Schoon H.A. \& Hoedemaker M. 2016. Prevalence of cervicitis in dairy cows and its effect on reproduction. Theriogenology 85:247-253.

Huszenicza G., Fodor M., Gacs M., Kulcsar M., Dohmen M.J.W., Vamos M., Porkolab L., Kegl T., Bartyik J., Lohuis J.A.C.M., Janosi S. \& Szita G. 1999. Uterine bacteriology, resumption of cyclic ovarian activity and fertility in postpartum cows kept in large-scale dairy herds. Reprod. Domest. Anim. 34(3/4):237-245.

Kasimanickam R., Duffield T.F., Foster R.A., Gartley C.J., Leslie K.E., Walton J.S. \& Johnson W.H. 2005. The effect of a single administration of cephapirin or cloprostenol on the reproductive performance of dairy cows with subclinical endometritis. Theriogenology 63:818-830.

Le Blanc S.J., Duffield T.F., Leslie K.E., Bateman K.G., Keefe G.P., Walton J.S. \& Johnson W.H. 2002. Defining and diagnosing postpartum clinical endometritis and its impact on reproductive performance in dairy cows. J. Dairy Sci. 85:2223-2236.

Mateus L., Costa L.L., Bernardo F. \& Silva J.R. 2002. Influence of puerperal uterine infection on uterine involution and postpartum ovarian activity in dairy cows. Reprod. Domest. Anim. 37(1):31-35.

McDougall S. 2001. Effect of intrauterine antibiotic treatment on reproductive performance of dairy cows following periparturient disease. $\mathrm{N}$. Z. Vet. J. 49:150-158.
Semambo D.K., Ayliffe T.R., Boyd J.S. \& Taylor D.J. 1991. Early abortion in cattle induced by experimental intrauterine infection with pure cultures of Actinomyces pyogenes. Vet. Rec. 129(1):12-16.

Sheldon I.M., Noakes D.E., Rycroft A.N., Pfeiffer D.U. \& Dobson H. 2002. Influence of uterine bacterial contamination after parturition on ovarian dominant follicle selection and follicle growth and function in cattle. Reproduction 123(6):837-845.

Sheldon I.M., Lewis G.S., Leblanc S. \& Gilbert R.0. 2006. Defining postpartum uterine disease in cattle. Theriogenology 65:1516-1530.

Sheldon I.M. 2009. Defining postpartum uterine disease and the mechanisms of infection and immunity in the female reproductive tract in cattle. Biol. Reprod. 81(6):1025-1032.

Thurmond M.C., Jameson C.M. \& Picanso J.P. 1993. Effect of intrauterine antimicrobial treatment in reducing alving-to-conception interval in cows with endometritis. J. Am. Vet. Med. Assoc. 203:1576-1578.

Watson E.D. 1990. Antibody response in the bovine genital tract to intrauterine infusion of Actinomyces pyogenes. Res. Vet. Sci. 48(1):70-75.

Williams E.J., Fischer D.P., England G.C.W., Dobson H., Pfeiffer D.U. \& Sheldon I.M. 2005. Clinical evaluation of postpartum vaginal mucus reflects uterine bacterial infection and the inflammatory response to endometritis in cattle. Theriogenology 63:102-117. 